\title{
An overview of airborne measurement in Nepal - Part 1: Vertical profile of aerosol size, number, spectral absorption, and meteorology
}

\author{
Ashish Singh ${ }^{1}$, Khadak S. Mahata ${ }^{1}$, Maheswar Rupakheti ${ }^{1}$, Wolfgang Junkermann ${ }^{2}$, Arnico K. Panday ${ }^{3}$, and \\ Mark G. Lawrence ${ }^{1}$ \\ ${ }^{1}$ Institute for Advanced Sustainability Studies, Potsdam, Germany \\ ${ }^{2}$ Institute of Meteorology and Climate Research, IMK-IFU, Garmisch-Partenkirchen, Germany \\ ${ }^{3}$ International Centre for Integrated Mountain Development (ICIMOD), Lalitpur, Nepal \\ Correspondence: Ashish Singh (ashish.singh@iass-potsdam.de) \\ and Maheswar Rupakheti (maheswar.rupakheti@iass-potsdam.de)
}

Received: 29 January 2018 - Discussion started: 3 April 2018

Revised: 23 November 2018 - Accepted: 10 December 2018 - Published: 8 January 2019

\begin{abstract}
The paper provides an overview of an airborne measurement campaign with a microlight aircraft over the Pokhara Valley region, Nepal, a metropolitan region in the central Himalayan foothills. This is the first aerial measurement in the central Himalayan foothill region, one of the polluted but relatively poorly sampled regions of the world. Conducted in two phases (in May 2016 and December 2016-January 2017), the goal of the overall campaign was to quantify the vertical distribution of aerosols over a polluted mountain valley in the Himalayan foothills, as well as to investigate the extent of regional transport of emissions into the Himalayas. This paper summarizes results from the first phase where test flights were conducted in May 2016 (pre-monsoon), with the objective of demonstrating the potential of airborne measurements in the region using a portable instrument package (size with housing case: $0.45 \mathrm{~m} \times 0.25 \mathrm{~m} \times 0.25 \mathrm{~m}, 15 \mathrm{~kg}$ ) onboard an ultralight aircraft (IKARUS-C42). A total of five sampling test flights were conducted (each lasting for 1-1.5 h) in the Pokhara Valley to characterize vertical profiles of aerosol properties such as aerosol number and size distribution $(0.3-2 \mu \mathrm{m})$, total particle concentration (>14 nm), aerosol absorption (370$950 \mathrm{~nm}$ ), black carbon (BC), and meteorological variables. Although some interesting observations were made during the test flight, the study is limited to a few days (and only a few hours of flight in total) and thus the analysis presented may not represent the entire pollution-meteorology interaction found in the Pokhara Valley.
\end{abstract}

The vertical profiles of aerosol species showed decreasing concentrations with altitude (815 to $4500 \mathrm{~m}$ a.s.l.); a steep concentration gradient below $2000 \mathrm{~m}$ a.s.l. in the morning; and mixed profiles (up to ca. $4000 \mathrm{ma.s.l}$ ) in the afternoon. The near-surface $(<1000 \mathrm{~m}$ a.s.l. $)$ BC concentrations observed in the Pokhara Valley were much lower than premonsoon BC concentrations in the Kathmandu Valley, and similar in range to Indo-Gangetic Plain (IGP) sites such as Kanpur in India. The sampling test flight also detected an elevated polluted aerosol layer (around $3000 \mathrm{~m}$ a.s.l.) over the Pokhara Valley, which could be associated with the regional transport. The total aerosol and black carbon concentration in the polluted layer was comparable with the near-surface values. The elevated polluted layer was also characterized by a high aerosol extinction coefficient (at $550 \mathrm{~nm}$ ) and was identified as smoke and a polluted dust layer. The observed shift in the westerlies (at $20-30^{\circ} \mathrm{N}$ ) entering Nepal during the test flight period could be an important factor for the presence of elevated polluted layers in the Pokhara Valley. 


\section{Introduction}

The Himalayas and surrounding regions are one of the unique ecosystems in the world, with a great variety in the geography and socio-economics, and a notable significance in the context of regional and global environmental change. Areas in the foothills of the Himalayas still constitute large regions of rural populations along with pockets of rapidly growing cities. Consequently, there is a complex interaction among changing emission sources and their interaction with regional and global climate change. Among emitted air pollutants, the chemical and physical properties of aerosols have been linked to significant burdens of disease, to melting of glaciers, to crop loses, to hydrological changes, and to cloud properties (Bollasina et al., 2011; Vinoj et al., 2014; Lau, 2014; Burney and Ramanathan, 2014; Brauer et al., 2012; Cong et al., 2015; Li et al., 2016).

Sources of aerosols in the Himalayas and the nearby IndoGangetic Plain (IGP) typically vary between urban, periurban, and rural locations; fossil fuel and industrial emissions such as vehicles, brick kilns, waste burning, or cement factories are typically urban and peri-urban; biomass cookstove, agriculture and waste burning and forest fires are often linked to emissions from rural areas (Guttikunda et al., 2014; Venkataraman et al., 2006; Stone et al., 2010). Secondary chemical pathways also contribute to the aerosols in the ultrafine and accumulation-mode range via particle formation events (Venzac et al., 2008; Neitola et al., 2011).

Aerosol properties in the Himalayas have large spatial and temporal variations, especially in the pre-monsoon and monsoon seasons. These observed variations are influenced by emission sources, regional meteorology, and geography (Dey and Di Girolamo, 2010). The influence of aerosol particles on local and regional weather during these adjacent seasons has significant implications for the timing, intensity, and spatial distribution of the summer monsoon in the region (Bollasina et al., 2011; Ramanathan et al., 2001). Studies describing the aerosol-meteorology interaction are often missing in the Himalayan region partly due to lack of surface and airborne measurements of aerosol properties along with meteorology. Most past campaign-mode measurements in the Himalayan regions, to our knowledge, have been ground measurements, which have aided in evaluating aerosol properties and their transformation and transport mechanisms (Shrestha et al., 2013, 2010; Ramana et al., 2004; Marcq et al., 2010; Panday and Prinn, 2009; Cho et al., 2017). Long-term continuous measurements of aerosols and meteorology are limited to a few stations in the High Himalayas, such as the recently discontinued Nepal Climate Observatory at Pyramid (NCOP, $27.95^{\circ} \mathrm{N}, 86.81^{\circ} \mathrm{E} ; 5050 \mathrm{~m}$ a.s.1.), a high-altitude observatory located near base camp of Mt. Everest. Columnar and satellite measurements such as AERONET and CALIPSO have provided a regional overview of aerosol type and vertical distribution, as well as estimation of the aerosol heating rate in the atmospheric column (Kuhlmann and Quaas, 2010;
Gautam et al., 2011; Pandey et al., 2017). However, these measurement techniques often suffer from large uncertainty and biases while retrieving the complex nature of the aerosols observed in the region (Jai Devi et al., 2011).

Regional meteorology in the $850-500 \mathrm{mb}$ range plays an important role in the transformation and transport of aerosols from western Asia to the IGP, the Himalayan foothills, and the Himalayan and Tibetan Plateau region (Decesari et al., 2010; Marinoni et al., 2013; Lüthi et al., 2015). At these altitudes, synoptic-scale air masses are mostly westerly/northwesterly during the pre-monsoon and southwesterly/easterly during the monsoon. These air masses are often linked to dust aerosol transport during the pre-monsoon season from western Asia into the Himalayas, including populated mountain valleys such as the Kathmandu Valley and Pokhara Valley in Nepal. The transported dust aerosol also mixes with the primary emission (or anthropogenic aerosols) in the IGP and accumulates from the northern to eastern IGP along the Himalayan foothills (Gautam et al., 2009b, 2011). The total aerosol loading is often highest during the pre-monsoon season in the IGP (Gautam et al., 2009a; Raatikainen et al., 2014), intensified further by weak surface/zonal winds and numerous open biomass burning and forest fire events (Kaskaoutis et al., 2012). The polluted aerosol layer in the IGP is advected into the Himalayas by synoptic-scale westerlies $(\sim 500 \mathrm{mb})$ and also by the valley wind circulation within or along the planetary boundary layer (PBL) (Lüthi et al., 2015). The advection is also facilitated by the strong updraft and PBL expansion (the highest in the premonsoon in the IGP) often mixing with the synoptic-scale westerlies (Raatikainen et al., 2014). Because of strong convective activity in the IGP, the polluted air masses near the surface are often lifted up to 5-7 km or higher (Kuhlmann and Quaas, 2010). In addition to the synoptic-scale transport, thermally driven valley winds also enable the transport of humid and polluted air mass (with enhanced absorbing fraction) from the IGP into the Himalayan foothills, and further up into the mountain valleys and elevated locations (Raatikainen et al., 2014; Lüthi et al., 2015; Gogoi et al., 2014; Putero et al., 2014; Decesari et al., 2010; Marcq et al., 2010). Strongly coupled with the expansion of the PBL in the IGP, the upslope movement of polluted air masses into the foothills and further east is characterized by late afternoon peaks in aerosol optical depth (AOD) in many measurement sites along the Himalayan range such as Hanle Valley (Ladakh, India), Mukteswar and Manora site (Nainital, India), Hetauda (Nepal), Langtang Valley (Nepal), Dhulikhel (Nepal), Kathmandu Valley (Nepal), and NCO-P (Nepal). The temporal and spatial extent of this observed "ventilation" at multiple locations could be more indicative of regionalscale transport than mesoscale transport (Gogoi et al., 2014; Raatikainen et al., 2014; Gautam et al., 2011; Putero et al., 2015; Marcq et al., 2010).

To date, there have been no observations of vertical distributions of aerosol and gaseous species carried out in the Hi- 
malayan region. Therefore, the airborne measurement campaign was designed to address two major questions: (i) what is the variation in the aerosol properties, notably the vertical distributions, over a polluted mountain valley, and (ii) what is the quantitative extent of regional transport of aerosols in the higher Himalayas. The campaign was carried out in two phases in the Pokhara Valley and surrounding areas in Nepal. In the first phase, test flights were conducted in May 2016 and, in the second phase, intensive sampling flights were carried out in December 2016-January 2017. This paper provides an overview of the measurement campaign and results from the test flights in May 2016 which include snapshots of vertical profiles of aerosol size, number, and composition, along with meteorological parameters. The airborne measurements presented in this paper are supplemented with observations of local and regional meteorology, as well as satellite and ground-based column-integrated aerosol microphysics and radiative properties (see Sect. 3.1.1 and 3.1.2; also Supplement S7). A companion paper will follow with more detailed observations and results based on the intensive measurements carried out during December 2016January 2017.

\section{Ultralight measurements in Nepal}

\subsection{Details of the airborne measurement unit}

A single-engine two-seater microlight aircraft (IKARUS C42, COMCO IKARUS, Germany) was used as the aerial platform. The technical specification of the aircraft includes approximately $4 \mathrm{~h}$ of flying time, a short take-off run, and an additional payload of up to $50 \mathrm{~kg}$, and it is suitable for small spiral movement in the air. The aircraft has a cruising speed of $165 \mathrm{~km} \mathrm{~h}^{-1}$ and a $5-6 \mathrm{~m} \mathrm{~s}^{-1}$ rate of climb, which make it an appropriate aerial vehicle for performing measurements at altitudes within the PBL and as close as $50 \mathrm{~m}$ above ground level. More details about the aircraft are available here (http://www.comco-ikarus.de/Pages/c42a-technik. php?lang=en, last access: 8 September 2017). Its size, speed, and maneuverability offered a decent climb to the free troposphere to capture vertical profiles in the rough terrains of Nepal. The aircraft used for the study is operated by the Pokhara Ultralight Company for recreational flights around the Pokhara Valley.

The instrument package was specifically designed and tested for aerial measurements (Junkermann, 2001). Table 1 describes each instrument and the integration performed to prepare the package for the aerial deployment. The instrument package consists of a GRIMM OPS (optical particle spectrometer) model 1.108 for particle size distributions $(0.3$ to $20 \mu \mathrm{m}, 16$ size bins) with sampling frequency of $6 \mathrm{~s}$, and a TSI condensation particle counter (CPC) 3760 for total particle concentration $(>14 \mathrm{~nm})$ at $1 \mathrm{~s}$ resolution (see Fig. S1 in the Supplement). The package also included a Magee Sci- entific aethalometer (AE42) for aerosol absorption at seven different wavelengths $(370-950 \mathrm{~nm})$. The instruments were reduced in weight for use on the aircraft. The CPC was operated with a constant mass flow and an internal direct current (DC) pump instead of the original flow regulation by a critical orifice. Meteorological parameters including temperature and dew point were sampled at a rate of $1 \mathrm{~s}$ using METEOLABOR (TPS3). All the sensors were connected to a modular computer (PC104) for data acquisition. The PC104 is also equipped with a Global Positioning System (GPS), and multiple serial and analog connectors. For inflight instrument checks and quick online overview of the atmospheric conditions, a small liquid crystal display (LCD) was also connected to the PC104 and placed in the cockpit areas for the flight crew. This display showed real-time aerosol number concentrations and meteorological parameters.

The instrument package weighs approximately $15 \mathrm{~kg}$ and consumes $<60 \mathrm{~W}$, well within the power supply range of the aircraft battery. It is housed in an aluminum box $(0.45 \mathrm{~m} \times 0.25 \mathrm{~m} \times 0.25 \mathrm{~m})$ and can be easily integrated with a mobile platform such as the IKARUS (see Fig. S1). In IKARUS, the instrument was placed in the rear section behind the seats which is otherwise almost empty or used for cargo, and only contains the fuel tank and supporting aluminum bars. The sample inlet line (internal diameter of $0.004 \mathrm{~m}$ or $\sim 4.0 \mathrm{~mm}$ ID brass tubing) ran along the wingspan and was approximately $1.8 \mathrm{~m}$ (in length, sampling tube) from the cockpit. Once the sample line is inside the aircraft, it is distributed to all the aerosol instruments using a simple metal flow splitter (0.006 m ID). No external pump was used to pull the aerosol into the sampling line, the total flow $\left(\sim 3.0 \mathrm{~L} \mathrm{~min}^{-1}\right)$ in the sampling line (before the split) was due to the internal pump of all the instruments. The sample inlet positioning at the end of the wingspan also minimizes the influence of the aircraft propeller, located in the front of the cockpit.

\subsection{Site description}

Pokhara Valley is Nepal's second largest populated valley (pop. > 250 000) after the Kathmandu Valley (CBS, 2011). The valley is approximately at $815 \mathrm{~m}$ a.s.l., $\sim 150 \mathrm{~km}$ west of the Kathmandu Valley, and $\sim 90 \mathrm{~km}$ northeast of the southern plains $(\sim 100 \mathrm{~m}$ a.s.l.) bordering the IGP. The valley is surrounded by mountains which are approximately 1000-2000 ma.s.l. Further north of the Pokhara Valley, within $30 \mathrm{~km}$ the elevation gradient increases rapidly to over $7000 \mathrm{~m}$ a.s.l. or higher (see Fig. 1). This steep elevation gradient is conducive to the orographic lift of humid air masses, and thus the valley also receives one of the highest rates of precipitation in Nepal and occasional strong convective updrafts leading to hailstorms and thunderstorms (Aryal et al., 2015). The mixing of dry westerly air masses with heated moist air masses from the Bay of Bengal produces strong convection over the Pokhara Valley, and thus results in strong 
Table 1. Instrument package deployed in the microlight aircraft.

\begin{tabular}{|c|c|c|c|}
\hline Parameters & Instruments & Method & $\begin{array}{l}\text { Sampling time } \\
\text { resolution }\end{array}$ \\
\hline Aerosol particle number size distribution $(0.3-20 \mu \mathrm{m})$ & GRIMM OPS 1.108 & Light scattering & $6 s$ \\
\hline Total particle number concentration $(>14 \mathrm{~nm})$ & TSI CPC 3760 & $\begin{array}{l}\text { Condensation/light scat- } \\
\text { tering }\end{array}$ & $1 \mathrm{~s}$ \\
\hline Aerosol spectral absorption & Magee AE42 & $\begin{array}{l}\text { Seven wavelengths, light } \\
\text { attenuation }\end{array}$ & $2 \mathrm{~min}$ \\
\hline Dew point sensor & METEOLABOR, TPS3 & Chilled mirror & $1 \mathrm{~Hz}$ \\
\hline Temperature & Thermocouple & - & $1 \mathrm{~Hz}$ \\
\hline Data acquisition system & PC $104+$ GPS & - & - \\
\hline Power supply & $\begin{array}{l}\text { Aircraft battery pack, } \\
\mathrm{LiFEPO}_{4} \text { battery }\end{array}$ & $12 \mathrm{~V},>15 \mathrm{AH}$ & \\
\hline
\end{tabular}

updrafts. These strong convective activities are frequent in the pre-monsoon and monsoon seasons but do not occur during the winter season.

\subsection{Test flight patterns over the Pokhara Valley}

Five test flights were conducted in the morning and evening periods around the Pokhara Valley $\left(83.97^{\circ} \mathrm{E}, 28.19^{\circ} \mathrm{N}\right.$, $815 \mathrm{~m}$ a.s.1.), with each flight lasting for about 1 to $1.5 \mathrm{~h}$ from 5 to 7 May 2016. The flight pattern was consistently flown over the northwestern part of the valley (Fig. 1). A typical flight commenced from the Pokhara Regional Airport (818 $\mathrm{m}$ a.s.1.) and steadily flew $5-10 \mathrm{~km}$ northwest along the Pokhara Valley, leaving the direct airport vicinity toward the Himalayas. This was followed by spirals up and down sampling from approximately 1000 to $4000 \mathrm{~m}$, often reaching close to the lower base of the clouds in the free troposphere. Further climbs into the cloud layer were avoided during the test flights.

\subsection{Data processing and quality}

The data from all the instruments were synced with the GPS clock, and the PC104 received all the data simultaneously and created a common time-stamped data file. Prior to each test flight, a zero test was conducted to identify any possible leaks in the sample line.

The collected data from the five test flights went through multiple steps of quality control and quality assurance. Occasionally during the radio communication by the pilot with the ground station or air traffic controller, the CPC and the temperature sensor would record exceedingly high values. This noise is an interference picked up by the sensors from the $5 \mathrm{~W}$ radio transmission. The $\mathrm{CPC}$ and aethalometer are also sensitive to vibration in the aircraft, especially during upward and downward spiral motion, which may result in flow imbalance in these analyzers. This resulted in random noise segments for a few seconds in the data, which were flagged and not included in the analysis.

\section{Results}

\subsection{General meteorology and air quality, aerosol properties in the Pokhara Valley}

\subsubsection{Local and synoptic meteorology in the Pokhara Valley}

Climatologically, the Pokhara Valley has a humid subtropical climate, characterized by a summer monsoon season from late June to September, preceded by a dry pre-monsoon season (March-May; see Fig. S2 in the Supplement). Dominant winds in the valley are from the southeast and southwest with a strong diurnal variability in the wind speed (Aryal et al., 2015). On a local/regional scale, the winds in May 2016 were predominantly from the southeast, with only occasional strong winds from the southwest (see Fig. S3 in the Supplement, using data available at the regional meteorological station at Pokhara Airport). During the test flight period (57 May 2016), the wind was similar in directionality, with an hourly mean wind speed of 1.8 to $3.0 \mathrm{~m} \mathrm{~s}^{-1}$, with low wind speed $\left(<2.0 \mathrm{~m} \mathrm{~s}^{-1}\right.$ ) before noon, usually from the southeast, followed by stronger winds from the southwest and northwest $\left(>2.4 \mathrm{~m} \mathrm{~s}^{-1}\right.$ ) which can continue until late night. The increased wind speed in the afternoon could be katabatic in nature as a result of differential heating of the mountain valley slopes and could be linked to pollution transport from surrounding regions (Gautam et al., 2011).

Three dominant synoptic meteorology regimes characterize the seasonality of southern Asia (Lawrence and Lelieveld, 2010). They are the summer (June-September), winter monsoon (mid-November to February), and monsoon-transition periods, which include the pre-monsoon season (MarchMay) and post-monsoon season (mid-September to midNovember). These synoptic regimes are also active in the Himalayas, including the Pokhara Valley. The monsoon transition period, during which the test flights were conducted, is characterized by westerlies over $20-30^{\circ} \mathrm{N}$ at $850 \mathrm{mb}$ and above (see Fig. 2). Figure 2 shows the daily wind vector over 


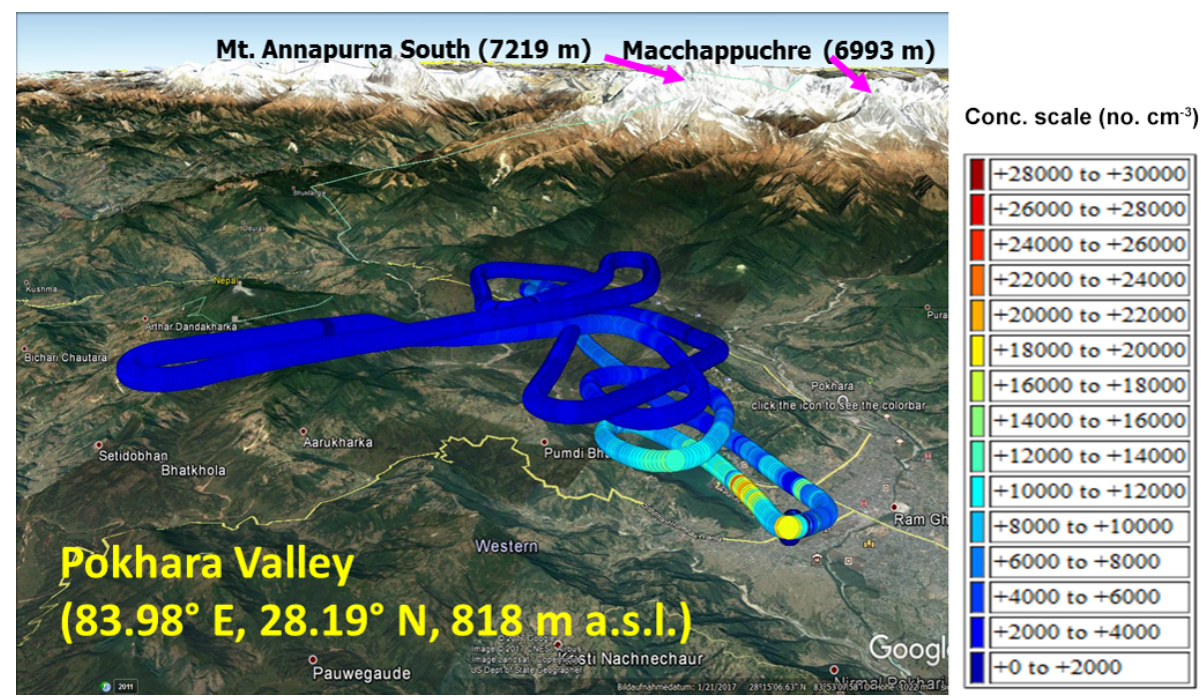

Figure 1. A typical test flight within the Pokhara Valley on 5 May 2016. The plot is generated using a Matlab-Google Earth toolbox (https://www.mathworks.com/matlabcentral/fileexchange/12954-google-earth-toolbox, last access: 3 March 2017, (OScott L. Davis). Each dot is a single sample point (sampling frequency of $1 \mathrm{~Hz}$ ); the color of the dot indicates the total aerosol number concentration and the value of each color is shown as a color bar.

southern Asia for 3, 5, 6, and 7 May 2016 generated using the NCEP NCAR Reanalysis data at $2.5^{\circ} \times 2.5^{\circ}$ horizontal resolution. While the reanalysis data can be expected to represent the synoptic-scale phenomena in this region reasonably well, the rough terrain in the Himalayas presents a significant challenge for modeling and the data are thus likely to suffer from biases and other deviations from the observed meteorology (Xie et al., 2007). The wind vector at $850 \mathrm{mb}$ in the $20-30^{\circ} \mathrm{N}$ latitude band was westerly with variable wind speeds in the IGP region near the Himalayan foothills. The wind direction varies diurnally at the $850 \mathrm{mb}$ level, with the wind direction shifting to southwesterly near the Himalayan foothills. Westerlies were also generally prevalent at $500 \mathrm{mb}$; however, in the mid-latitudes between 40 and $50^{\circ} \mathrm{N}$ (central Asia), a trough and crest-like feature of the westerlies moving from western to eastern Asia are visible (also observed by Lüthi et al., 2015), which were also present prior to the study period. This wind feature was colder and more humid (see Fig. S4 in the Supplement) than the westerlies observed between 20 and $30^{\circ} \mathrm{N}$. The meandering features (i.e., trough and crest) observed between 40 and $50^{\circ} \mathrm{N}$ affect the direction and magnitude of air masses (at $20-30^{\circ} \mathrm{N}$ ) entering Nepal. For instance, the crest feature of the Westerly was prevalent over the IGP and Nepal prior to 3 May, transitioned into the trough feature after 3 May, and continued during the study period. The prevalence of the trough was characterized by the intrusion of wind into lower latitudes as well as into the IGP, also indicated by the change in the temperature and humidity (Fig. S4). The intrusions of mid-latitude air masses also influence the westerlies entering Nepal in the $20-30^{\circ} \mathrm{N}$ sector (Lüthi et al., 2015). As discussed later, variations in the vertical profiles of aerosols above $3000 \mathrm{~m}$ a.s.l. could be associated with variations observed in these upper-layer winds.

\subsubsection{Overview of the aerosol properties in the Pokhara Valley during the test flight period}

The variation in aerosol loading (as reflected by AOD) reveals a strong seasonality in the Pokhara Valley (see Fig. S7 in the Supplement for a detailed description of aerosol properties in the Pokhara Valley during 2010-2016). The premonsoon season (also the time of the test flight) has the highest AOD values $\left(\mathrm{AOD}_{500 \mathrm{~nm}}>0.6\right.$ : Figs. S7a, $\mathrm{b}$, and S5) followed by the monsoon low ( $\mathrm{AOD}_{500 \mathrm{~nm}} \sim 0.2-0.3$ ), most likely due to the wet removal of aerosols. AOD gradually increased (to $\sim 0.4-0.5$ ) during the post-monsoon through winter to the pre-monsoon season. Generally, the increase in total AOD (sum of fine and coarse) over the Pokhara Valley is dominated by fine-mode aerosol particles, except during the pre-monsoon and monsoon seasons, when a substantial fraction of coarse-mode particles were also present. The dominant aerosol in the Pokhara Valley is mostly BC-like (Giles et al., 2012), based on the values of absorption and extinction Ångstrom exponent (AAE and EAE at $440-870 \mathrm{~nm}$ ); however, a substantial seasonal variation was observed from more mixed or dust-like in the pre-monsoon months to more $\mathrm{BC}$-like in the post-monsoon and winter months.

The aerosol optical properties (columnar) and synoptic meteorology are shown in Figs. 3 and S6 (in the Supplement). Prior to the flight days (1-4 May), higher AOD values were recorded in the Pokhara Valley $(\mathrm{AOD}>1)$ and dominated by a fine-mode fraction $(\sim 0.95)$. Hazy condition and low visibility $(\leq 5 \mathrm{~km})$ were recorded during the period in 


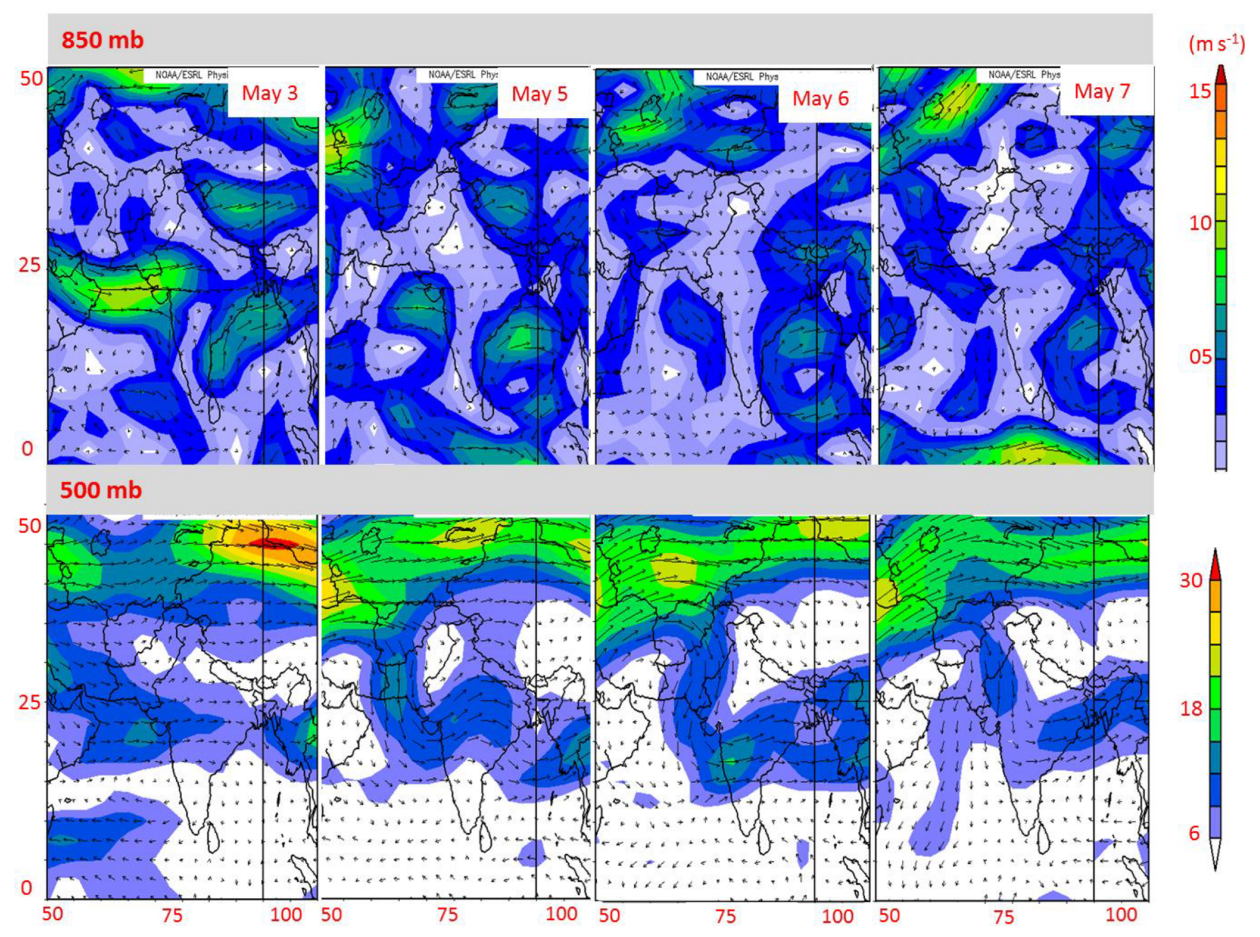

Figure 2. Daily wind vector data at 850 and $500 \mathrm{mb}$, plotted using the NCEP NCAR reanalysis $\left(2.5^{\circ} \times 2.5^{\circ}\right)$ data over southern Asia from 1 to 7 May 2016. The colors indicate the wind speed in $\mathrm{m} \mathrm{s}^{-1}$. The plots were generated using the default setup at https://www.esrl.noaa.gov/ psd/data/composites/day/ (last access: 4 May 2017).
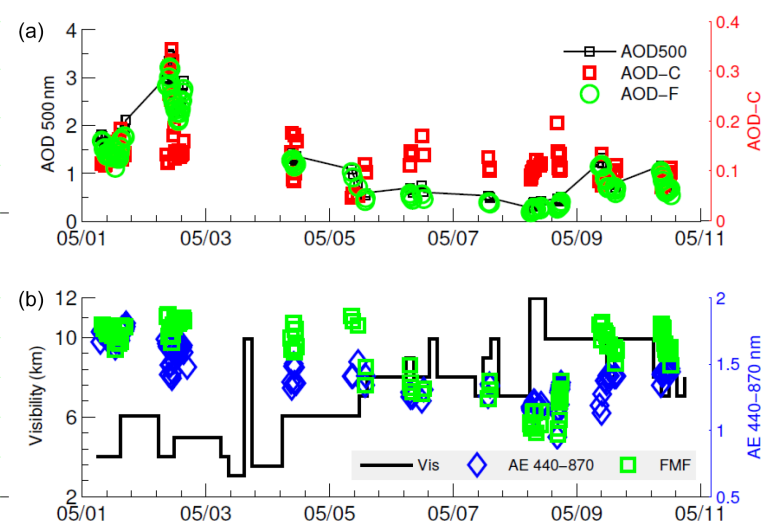

Figure 3. AOD and other data products from the Level 1.5 AERONET direct product in the Pokhara Valley from 1 to 10 May 2016. The top panel includes AOD at $500 \mathrm{~nm}$ and the AOD for coarse and fine modes (as shown in the figure above as AOD$\mathrm{C}$ and AOD-F). The bottom panel includes the Ångström exponent (AE) for $440-870 \mathrm{~nm}$, the fine-mode fraction, and the visibility $(\mathrm{km})$. The visibility data were available from the synoptic meteorology data available at http://www7.ncdc.noaa.gov/CDO/cdo (last access: 3 July 2018).

the valley (see Fig. S6). Moving into the flight days, the AOD values decreased below 1 , markedly by the drop in the finemode fraction and the improvement in haze condition and visibility. The flight day periods were also characterized by the presence of scattered clouds and thunderstorms (with no precipitation) in the afternoon, which also implies conditions for the strong vertical mixing of pollutants. It is indicative from Figs. 3 and S7 that the presence of high levels of pollution over the region from 1 to 4 May is followed by a short period of (relatively) cleaner conditions, which also coincides with the changes in the synoptic situation observed in the winds at $500 \mathrm{mb}$ (described in Sect. 3.1.1).

\subsection{Vertical profiles of absorbing aerosols, particle number and size distribution, temperature, and dew point}

The five test flights are labeled as F1-5 in Fig. 4, except F3, which is shown in the Supplement (Fig. S10). F1 and F2 were conducted on 5 May, F3 and F4 on 6 May, and F5 on 7 May 2016. Due to limitations of the flight permit, the test flights were conducted, remaining within the Pokhara Valley as indicated by Fig. 1. Among the five sampling flights, F1, $\mathrm{F} 3$, and F5 were morning flights, and F2 and F4 were afternoon flights (for details on sampling flights, see Table S1 in the Supplement).

\subsubsection{Diurnal variation in the vertical profiles}

All the vertical aerosol profiles (Fig. 3) showed a strong gradient below $2000 \mathrm{~m}$ a.s.l. Because of the valley geogra- 

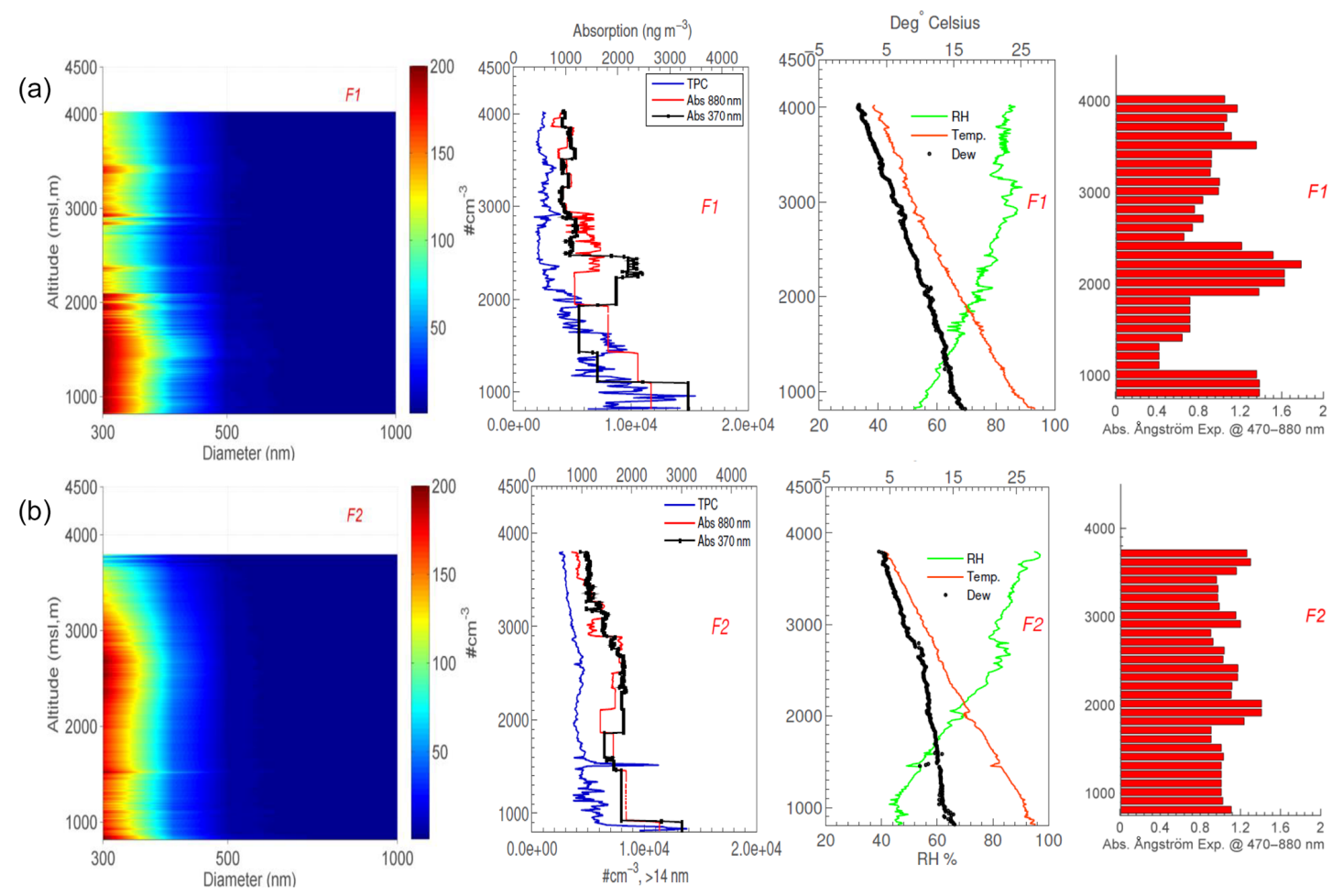

(c)
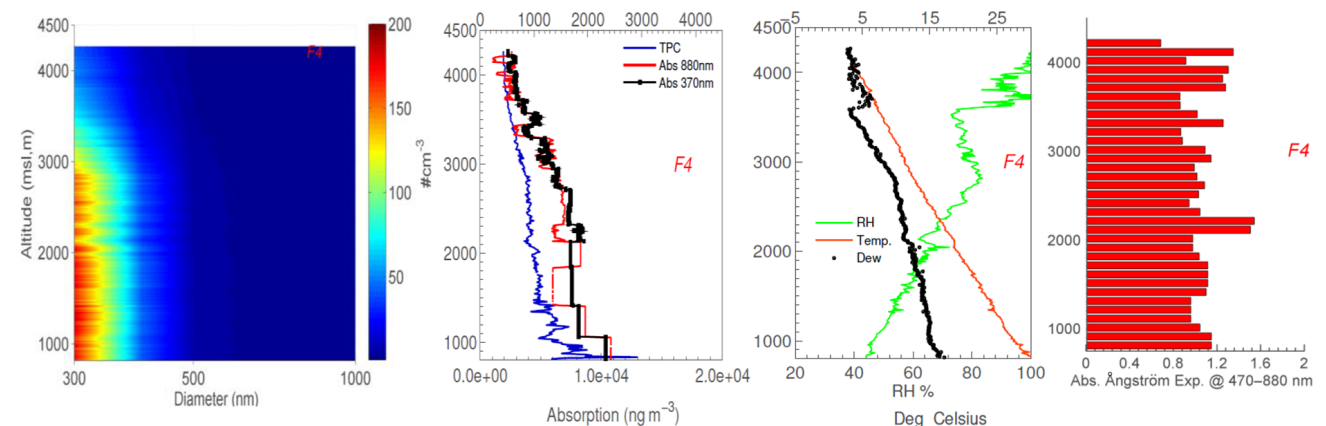

(d)
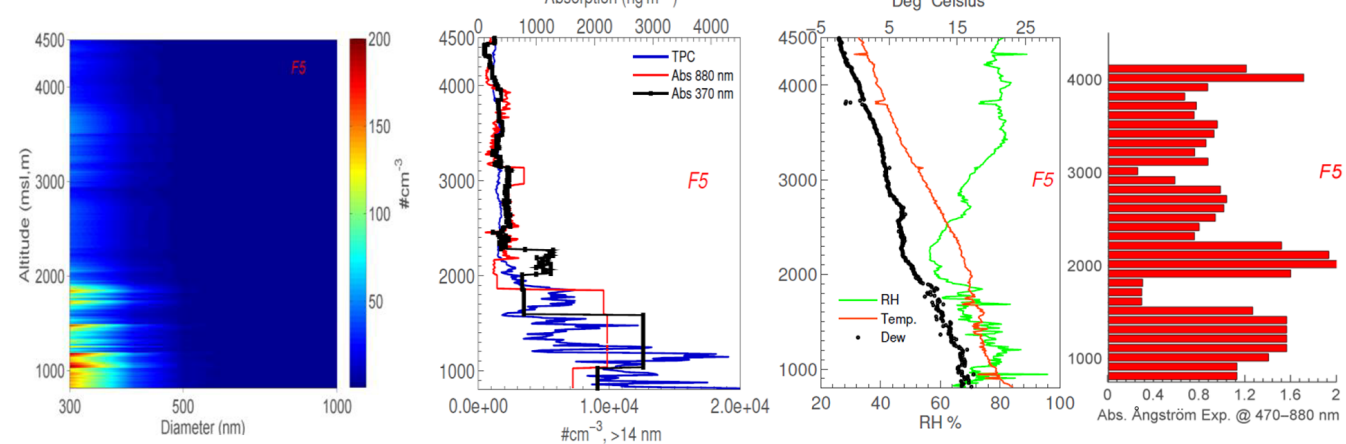

Figure 4. Vertical profiles of aerosol species and meteorological parameters during the 5-7 May 2016 test flights in the Pokhara Valley using the IKARUS microlight aircraft. The subplot in each row is arranged by (i) size distribution measured by the GRIMM OPS 1.108 $(0.3-20 \mu \mathrm{m})$, limited to $1 \mu \mathrm{m}$ in the figure, (ii) total particle number concentration (also indicated as TPC, $D_{\mathrm{p}}>14 \mathrm{~nm}$ ) measured by the CPC 3760, along with absorbing aerosol mass density at 370 and $880 \mathrm{~nm}$ (iii) temperature (red line, in ${ }^{\circ} \mathrm{C}$ ) and dew point (black dots, in ${ }^{\circ} \mathrm{C}$ ) and relative humidity (or RH \%), and (iv) calculated absorption Ångstrom exponent averaged for every $100 \mathrm{~m}$ elevation band. For the size distribution plot, the $x$ axis represents the optical diameter of the aerosol $(\mathrm{nm})$ and the color bar represents the concentration $\left(10^{x}\right.$ in no. $\mathrm{cm}^{-3}$ ). Of the five test flights, only F1-2 and F4-5 are shown here (a-d); F3 is in the Supplement (Fig. S10). Number size distribution data from Flight F3 are not available due to the failure of Grimm's pump during flight initiation. In each subplot, the $y$ axis is the altitude above the mean sea level (in $\mathrm{m}$ ). The origin of the $y$ axis is at $815 \mathrm{~m}$ a.s.l. 
phy, with surrounding mountains of about $\sim 2000 \mathrm{~m}$ a.s.l. or higher, it is likely that the gradient observed below $2000 \mathrm{~m}$ a.s.l. could be related to emissions from the Pokhara Valley. The development (or dissolution) of the boundary layer during the day clearly influenced the evolution of the aerosol vertical profiles in the Pokhara Valley. The shallow boundary layer in the night, which continued till the morning, led to the accumulation of aerosols below $2000 \mathrm{~m}$ a.s.l. in the morning (see the morning flights F1, F3, and F5) and a strong decrease with altitude was observed. For instance, in the morning profiles, the concentrations near the surface $(<$ $1000 \mathrm{~m}$ a.s.l.) for total particle number concentrations (also indicated as TPC in Fig. 4) were mostly $>10^{3} \mathrm{~cm}^{-3}$, but could reach $\sim 3 \times 10^{4} \mathrm{~cm}^{-3}$ or higher (see F5 in Fig. 4), which is attributed to the coupling of the shallow boundary layer and the emissions in the contained valley topography (Mues et al., 2017). Also, all the measured aerosol parameters (number size distribution for particles with diameters between 0.3 and $0.5 \mu \mathrm{m}$ ), the total particle concentration $(>14 \mathrm{~nm})$, and the absorption vary similarly as a function of the altitude irrespective of the timing of the profiles. The similarity in the vertical concentration gradients of the absorbing aerosol mass concentrations and the aerosol number concentration above $2000 \mathrm{~m}$ a.s.l. provides evidence of similar emission sources or origins.

Within the morning profiles, substantial variations were observed; in F1 (5 May), in addition to the strong gradient below $2000 \mathrm{~m}$ a.s.l., there is a polluted layer above $3000 \mathrm{~m}$ a.s.l. which is not evident in F5. The BC concentration was close to $1 \mu \mathrm{g} \mathrm{m}{ }^{-3}$ up to $4000 \mathrm{~m}$ a.s.l. for $\mathrm{F} 1$ and stayed in that range until F5, where it dropped to about $\sim 0.4 \mu \mathrm{g} \mathrm{m}^{-3}$. The temperature and humidity profile also showed changes between the morning flights; the conditions during F1 are warmer (throughout the profile) and dryer (near the surface), compared to F5. This observed variation in the aerosol vertical profile (including the meteorology) may be indicative of cleaner atmospheric conditions (in terms of aerosol number and absorption) from 5 to 7 May and could be associated with the arrival of colder air masses in the Pokhara Valley. The near-surface $\mathrm{BC}$ concentrations measured in this study were much lower than surface $\mathrm{BC}$ concentrations measured in the pre-monsoon season (2013) in the Kathmandu Valley in the Himalayan foothills (hourly average: $\sim 5-40 \mu \mathrm{g} \mathrm{m}^{-3}$, Mues et al., 2017), but comparable to winter measurements (2004) in Kanpur in the IGP (1-3 min average: $\sim 1-7 \mu \mathrm{g} \mathrm{m}^{-3}$, Tripathi et al., 2005). In Kanpur, Tripathi et al. (2005) observed $\mathrm{BC}$ concentrations close to $1 \mu \mathrm{g} \mathrm{m}{ }^{-3}$ up to $2000 \mathrm{~m}$ a.s.l. and a sharp gradient below $400 \mathrm{~m}$ a.s.l., most likely due to a shallow boundary layer in winter.

The elevated polluted air mass in F1 could be an indication of transport related to the mountain valley winds and/or synoptic transport related to the Westerlies, common during this season (Gautam et al., 2011; Raatikainen et al., 2014; Marcq et al., 2010). Pre-monsoon airborne measurements over the IGP and near the Himalayan foothills during CALIPEX-
2009 found a polluted aerosol layer $\left(2-4 \times 10^{3} \mathrm{~cm}^{-3}\right.$ with a mean size of $0.13 \mu \mathrm{m}$ diameter) below $4 \mathrm{~km}$ (a.s.l), attributed to biomass burning observed during this particular season (Padmakumari et al., 2013).

The afternoon profiles (F2: 5 May 2016 and F4: 6 May 2016), in contrast to the corresponding morning profile (F1 and F3), showed a more relatively mixed profile up to about $2500-3000 \mathrm{~m}$, decreasing then up to the maximum sampled altitude of just above $4000 \mathrm{~m}$ a.s.l. For instance, the concentrations of measured aerosol parameters up to $3000 \mathrm{~m}$ a.s.l. were comparable to the concentrations observed at $\sim 1000 \mathrm{~m}$ a.s.l. Slight differences exist within the afternoon profiles, which may be related to local meteorology (boundary-layer evolution) and mountain valley wind circulation in the afternoon. Cloud layers were present during the afternoon flights at and above $4000 \mathrm{~m}$ a.s.l. in F4 (also indicated by the sharp rise in RH from ca. $3600 \mathrm{~m}$ a.s.l.), which may have led to the scavenging of the aerosol by cloud droplets, thus explaining the observed decrease in the measured aerosol parameters.

\subsubsection{Nature of absorbing aerosols in the Pokhara Valley}

The absorption at multiple wavelengths was used to calculate the absorption Ångstrom exponent (AAE), shown in the right-most subplot in each row of Fig. 4. The AAE characterizes the wavelength $(\lambda)$ dependence of the absorption coefficient (absorption coefficient or abs. coeff $=K \lambda^{-\mathrm{AAE}}$, Russell et al., 2010; Giles et al., 2012). On a logarithmic scale, the above power relation between absorption coefficient and wavelength is approximately a straight line (see Fig. S11 for an example case where both power and logarithmic form are plotted). The slope of the straight line is the AAE. In our case, all the absorption coefficients measured between the 470 and $880 \mathrm{~nm}$ wavelengths were used for the calculation of the AAE. The mass absorption coefficients (MACs) of 14.5 and $7.77 \mathrm{~m}^{2} \mathrm{~g}^{-1}$, as prescribed by the manufacturer of the aethalometer (Hansen et al., 1984) for wavelengths 470 and $880 \mathrm{~nm}$, respectively, were used to calculate the absorption coefficient (the unit for the absorption coefficient is $\mathrm{m}^{-1}$ ). The calculated AAE was averaged for each $100 \mathrm{~m}$ a.s.l., as shown in the figure. The sampling resolution for the aethalometer is $2 \mathrm{~min}$ (see Table 1), which resulted in no (in a few cases) or few (after flagging) data if smaller height bins were chosen. The AAE profile differed markedly between the morning (F1, F3, and F5) and afternoon (F2 and F4) profiles, with morning profiles showing large variations along the height. The surface AAE $(\sim 1000 \mathrm{~m}$ a.s.l. $)$ was close to 0.8 to 1.2 for all the flights, which indicates the presence of $\mathrm{BC}$ from a mix of sources (biomass burning and fossil fuel combustion). A source-diagnostic analysis of C-isotopes of elemental carbon (EC) in TSPs (total suspended particulates) collected in Pokhara during April 2013March 2014 showed that the biomass burning and fossil fuel 
(a)
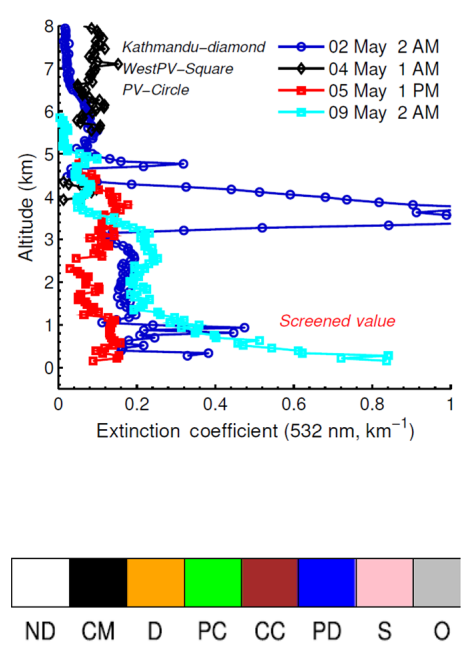

ND-not detected, CM: clean marine, D:dust PC: polluted continental, PD: polluted dust; CC: clean continental, S: smoke, $\mathbf{O}$ : others
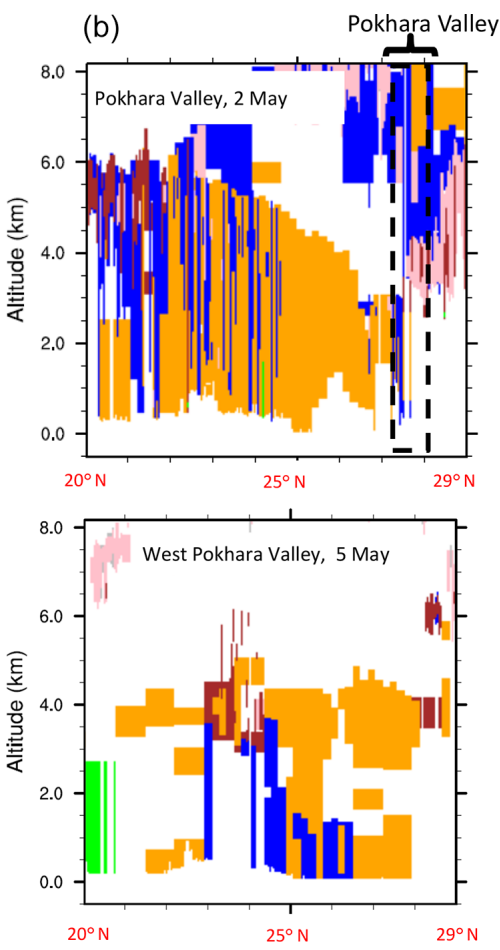
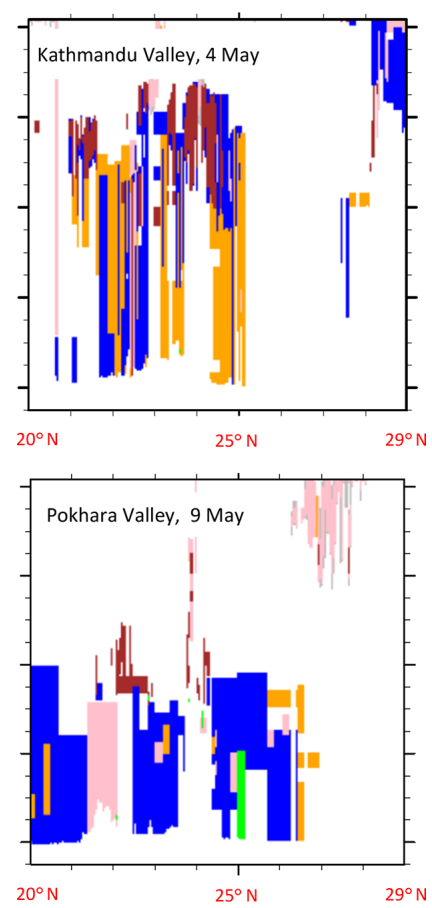

Figure 5. Aerosol extinction coefficient (at $532 \mathrm{~nm}$ ) vertical profile (a) and aerosol type classification based on the CALIPSO level 2 retrieval (b). Only the CALIPSO overpass over the Pokhara Valley or nearby locations (such as the Kathmandu Valley region and the region to the west of the Pokhara Valley) is included. The extinction profile is averaged for the region $27-28.5^{\circ} \mathrm{N}$ latitude, which also includes the Pokhara Valley. The satellite overpass time is shown in Nepal Standard Time (NST).

combustion contributes nearly $50 \%$ each to the (annual average) EC concentration ( $\mathrm{Li}$ et al., 2016). The AAE values above the surface ( $>1000$ ma.s.l.) varied from 0.5 to 2 , but mostly fell into the range of $0.9-1.2$, which is typically reported for mixed to $B C$-like aerosols from urban and industrial emissions (Russell et al., 2010; Yang et al., 2009; Dumka et al., 2014). AAE $<1$ could also be indicative of a composite aerosol, where a BC aerosol (or "core") is coated with absorbing or non-absorbing aerosols (Gyawali et al., 2009).

\subsubsection{Comparison of the satellite-derived vertical profiles with measurements}

The measured vertical profiles were also complemented with CALIPSO retrievals over the Pokhara Valley (Fig. 5). Level 2 (version 4), cloud, and quality screened data were used to generate the vertically resolved extinction (at $532 \mathrm{~nm}$ ) and aerosol classification. The CALIPSO satellite had only three overpasses over the Pokhara Valley between 1 and 10 May 2016 (the extinction profile lines with circle markers are for the Pokhara Valley). Therefore, the satellite overpasses through nearby regions such as the Kathmandu Valley region to the east and the region to the west of the Pokhara Valley (denoted by WestPV in Fig. 5) were also considered. The range of extinction values for the Pokhara Val- ley $\left(0.15-0.25 \mathrm{~km}^{-1}\right.$ especially around $2000-4000 \mathrm{~m}$ a.s.1.) were similar to pre-monsoon values $\left(0.15-3 \mathrm{~km}^{-1}\right)$ reported in Nainital (a hilly station located $\sim 2000 \mathrm{~m}$ a.s.l. in India, and $400 \mathrm{~km}$ west of the Pokhara Valley) and slightly less than Kanpur, a site in the IGP, about $400 \mathrm{~km}$ to the southwest of Pokhara (Dumka et al., 2014). A large extinction $\left(>0.5 \mathrm{~km}^{-1}\right)$ was observed on 1 May 2016 over the Pokhara Valley at an altitude of 3-4 km a.s.l., which can be attributed to smoke (biomass-related) and polluted dust (a mixture of dust and biomass smoke or urban pollution) as evident by the aerosol type classification. Aerosols over the IGP and in the proximity of the Himalayan foothills were mainly "Dust" on 1 May 2016. Although not conclusive, the 9 May aerosol type classification is markedly different from 1 May with the absence of dust in the IGP and the absence of polluted dust or smoke over the Pokhara Valley.

\subsubsection{Role of synoptic circulation in modulating aerosol properties over the Pokhara Valley}

The measured vertical profiles and available satellite data from MODIS (see Fig. S8) and CALIPSO suggest that the synoptic-scale circulation was changing during the study period. The changing synoptic circulation also influenced the transport of polluted air into the Pokhara Valley. The regional meteorology station in the Pokhara Valley reported 

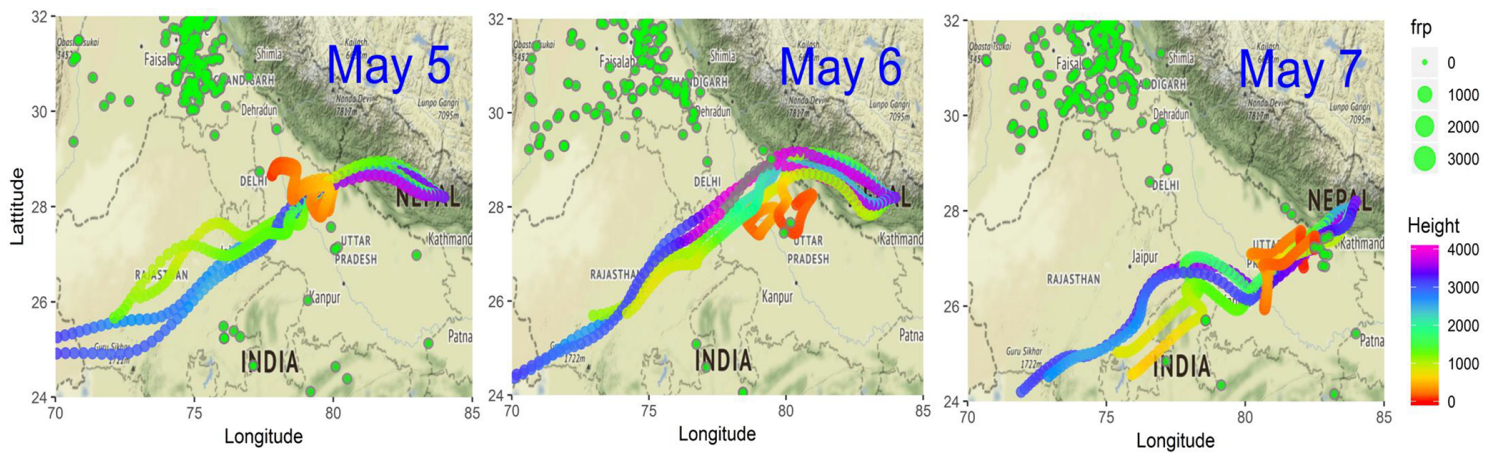

Figure 6. HYSPLIT (Hybrid Single Particle Lagrangian Integrated Trajectory, Draxler and Hess, 1998) 3-day back trajectories of air masses arriving at three different heights $(800,1500$, and $2500 \mathrm{~m})$ from above the ground level (a.g.1. $\sim 815 \mathrm{~m}$ a.s.1.) in the Pokhara Valley $\left(28.19^{\circ} \mathrm{N}\right.$, 83.98 ${ }^{\circ}$ E) during 5-7 May 2016. NCEP GDAS (Global Data Assimilation System) Reanalysis data with $1^{\circ} \times 1^{\circ}$ horizontal resolution were used as the input meteorology. The trajectory data are overlayed with the active fire data (extracted from the MODIS collection 6 database, available at https://firms2.modaps.eosdis.nasa.gov/active_fire/ (last access: 10 October 2018). Each green dot with a gray edge is an active fire, and the strength of the active fire is indicated by the "frp" value, which is the fire radiative power in megawatts.

hazy conditions till 5 May 2016 (see Fig. S6) which disappeared from 6 May 2016 onwards followed by clear days with scattered clouds during the daytime and thunderstorms in the afternoon. The variation in the AOD, AOD-F, and finemode fraction (FMF) from AERONET (only level 1.5 data were available; see Fig. S7) also showed high turbidity in the atmospheric column, dominated by fine-mode aerosols before 5 May $2016\left(\mathrm{AOD}_{500 \mathrm{~nm}}>2.0\right.$, FMF $\left.>0.9\right)$, which declined sharply after 5 May 2016. The variation in the horizontal visibility (or visual range) measured at the meteorology station in the Pokhara Valley further indicates that the intensity of pollution declined during the study period, especially starting on 5 May 2016.

Three-day back trajectories $(72 \mathrm{~h})$ were generated using HYSPLIT (Hybrid Single Particle Lagrangian Integrated Trajectory) for air masses arriving in the Pokhara Valley at 800,1500 , and $2500 \mathrm{~m}$ from above ground level (a.g.l.) for the test flight period (see Fig. 6). The NCEP GDAS reanalysis data with a $1^{\circ} \times 1^{\circ}$ horizontal resolution were used as the input meteorology for the trajectories. The majority of the air masses (especially at 1500 and $2000 \mathrm{~m}$ a.g.l.) were westerly. A high-resolution $\left(0.0625^{\circ}\right.$ horizontal $)$ simulation of air mass trajectories during the pre-monsoon period over the Himalayas and Tibetan Plateau region by Lüthi et al. (2015) also identified synoptic-scale transport (as westerly advection around $500 \mathrm{mb}$ ) and a convection-enabled polluted air mass from the IGP as a major mechanism of transport of air pollution in the Himalayas. Transport of air pollution by both mechanisms was coupled with the diurnal expansion of PBL height in the IGP where the trajectory height was similar to planetary boundary layer (PBL) height, thus allowing mixing up of the polluted layer, also observed by Raatikainen et al. (2014) over Gual Pahari (IGP site) and Mukteswor (Himalayan foothill site).
During the study period, the direction of the trajectories varied as the air masses entered Nepal and eventually into the Pokhara Valley. On 5 and 6 May 2016, the air masses (at 1500 and $2000 \mathrm{~m}$ a.g.l.) were mostly northwesterly, traversing through northern India and western Nepal before entering the Pokhara Valley. A shift in the trajectory direction from northwesterly to southwesterly was observed on 7 May 2016, where the trajectories were moving through central India and the southern foothills into the Pokhara Valley. The observed shift in the trajectories at 1500 and $2500 \mathrm{~m}$ a.g.l. was modulated by the synoptic-scale changes in the mid-latitude (over central Asia) air masses $\left(40-50^{\circ} \mathrm{N}\right)$ (Lüthi et al., 2015). The intrusion (in the form of a trough) of the cold and humid air masses from 40 to $50^{\circ} \mathrm{N}$ (see Fig. 2) into $20-30^{\circ} \mathrm{N}$ occurred during the study period. As the trough moves eastward, it shifts the synoptic air mass at $20-30^{\circ} \mathrm{N}$ from northwesterly to southwesterly on 7 May 2016. The elevated polluted layer on 5 and 6 May 2016 (Fig. 4) could be the result of this modulation of the westerly. The northwesterly air mass entered Nepal via northern India, where MODIS retrievals showed a high aerosol loading (see Fig. S8), which could be mainly attributed to the numerous biomass fire events (see Fig. S9) observed in northern India. In addition, numerous forest fires were also reported in western Nepal during the same period. However, the absorption signal from the flight measurement does not clearly show higher absorption at shorter wavelengths compared to absorption at $880 \mathrm{~nm}$ or longer wavelengths. This also implies that the observed elevated polluted layer in the Pokhara Valley is not entirely due to the biomass burning plume intercepted by the westerlies or northwesterlies. As the air-mass origin shifts to southwesterly on 7 May 2016 (detected during flight F5), the synoptic air mass bypassed the high AOD loading over northern India and contained the cold and relatively clean air from central 
Asia. This resulted in the disappearance of the polluted layer over $2000 \mathrm{~m}$ a.s.1. during flight F5.

\section{Conclusion}

This paper provides an overview of the pre-monsoon airborne measurement carried out with a microlight aircraft platform in the Pokhara Valley in Nepal, the first-oftheir-kind airborne aerosol measurements in the Himalayan foothill region. The objective of the overall airborne campaign in the Himalayan region was to quantify the vertical distribution of aerosols over a polluted mountain valley region, as well as to measure the extent of regional transport into the Himalayas. In this paper, measurements from the test flights during May 2016 are summarized. These mainly include vertical profiles of aerosol number and size distribution, multi-wavelength aerosol absorption, black carbon, total particle concentration, and meteorological variables. The instrument package, designed for a microlight sampling, was fitted to an IKARUS-C42 microlight aircraft. A total of five test flights were conducted between 5 and 7 May 2016, including morning and evening flights for about $1-1.5 \mathrm{~h}$ each, as well as vertical spirals to characterize vertical profiles of aerosols and meteorological parameters.

The results presented in this paper should be considered as a pilot study mapping out the aerosol concentrations and their interactions with meteorological processes in the Pokhara Valley due to the limited flight time. In all the measured flights, the vertical profiles of aerosol parameters showed strong gradients along the atmospheric column. The observed total number concentration gradient was strongly influenced by the mountain valley boundary layer, which resulted in a sharp gradient below about 1500-2000 ma.s.l. The increase in boundary-layer height contributed to the differences in the morning and afternoon profiles. Similar vertical profiles of $\mathrm{BC}$ concentrations and aerosol total particle number concentrations provided evidence of common emission sources or co-located origins. The observed BC concentration near the surface $(\sim 1000 \mathrm{~m}$ a.s.l.) was much lower than pre-monsoon $\mathrm{BC}$ concentrations measured in the Kathmandu Valley but comparable to values reported during the winter season in Kanpur in the IGP. The AAE estimates near the surface, based on the absorption value, fell in the range of 0.9-1.2, which indicates the presence of $B C$-like and mixed (dust, urban, biomass) aerosols. An elevated polluted layer was observed at around $3 \mathrm{~km}$ a.s.l. over the Pokhara Valley during this study. Characterized by a strong presence of dust in the IGP and polluted continental air masses over the Pokhara Valley, the polluted layer could be linked with the westerly synoptic circulations and regional transport from the IGP and surrounding regions. The direction of the synoptic transport entering the Himalayan foothills and the Pokhara Valley, however, was influenced by the Westerlies at mid-latitudes $\left(40-50^{\circ} \mathrm{N}\right)$. The extent of transport can be bet- ter quantified with regional airborne measurements along the south-north transect through the region between the IGP and the Himalayan foothills at high altitudes in the Himalayas, including the Pokhara Valley. We will explore the extent of such regional transport in a subsequent publication that will be primarily based on the airborne measurements in phase II (December 2016-January 2017) in the Pokhara Valley and in the surrounding region. The subsequent paper will also characterize the extent of vertical transport from three different mountain valleys located at different elevations along the south-north transect.

Data availability. The main data (flight data) used during the study is the original work of the author and belongs to IASS (affiliated institution). The author and team is working on an another publication (Part 2), which is using the current data set for modelling analysis. After the completion of Part 2, the plan is to make data available in one of the DOI repositories.

Supplement. The supplement related to this article is available online at: https://doi.org/10.5194/acp-19-245-2019-supplement.

Author contributions. WJ, AS and MR designed the sampling and flight plan. AS and WJ conducted the field sampling. AS conducted the complete data analysis, and manuscript drafting with assistance from KM, WJ, MR, ML, and AP.

Competing interests. The authors declare that they have no conflict of interest.

Acknowledgements. The authors would like to thank the Ministry of Population and Environment, Nepal (http://www.mope.gov.np, last access: 4 January 2017), and the Civil Aviation Authority of Nepal (https://www.caanepal.org.np, last access: 4 January 2017) for approving this campaign in Nepal. We are grateful for funding for IASS and for this study from the German Federal Ministry for Education and Research (BMBF) and the Brandenburg Ministry for Science, Research and Culture (MWFK). We would also like to thank the NASA DAACs for the data repository of MODIS, and the CALIPSO satellite as well as NOAA for the meteorology data. Special thanks to the NASA AERONET team, especially Gupta Giri, for operating and maintaining the Pokhara station. The work was only possible through the support and teamwork of the Pokhara Ultralight Company and their operational staff for aircraft and air traffic management.

Edited by: Tuukka Petäjä

Reviewed by: three anonymous referees 


\section{References}

Aryal, D., Rosoff, Y. N., and Devkota, L. P.: A Severe Hailstorm at Pokhara: CAPE Stability Index Calculations, Journal of Geosciences and Geomatics, 3, 142-153, 2015.

Bollasina, M. A., Ming, Y., and Ramaswamy, V.: Anthropogenic Aerosols and the Weakening of the South Asian Summer Monsoon, Science, 334, 502-505, https://doi.org/10.1126/science.1204994, 2011.

Brauer, M., Amann, M., Burnett, R. T., Cohen, A., Dentener, F., Ezzati, M., Henderson, S. B., Krzyzanowski, M., Martin, R. V., Van Dingenen, R., van Donkelaar, A., and Thurston, G. D.: Exposure assessment for estimation of the global burden of disease attributable to outdoor air pollution, Environ. Sci. Technol., 46, 652-660, https://doi.org/10.1021/es2025752, 2012.

Burney, J. and Ramanathan, V.: Recent climate and air pollution impacts on Indian agriculture, P. Natl. Acad. Sci. USA, 111, 1631916324, https://doi.org/10.1073/pnas.1317275111, 2014.

CBS: National Population and Housing Census 2011, National Planning Commission Secretariat, Kathmandu, 2011.

Cho, C., Kim, S.-W., Rupakheti, M., Park, J.-S., Panday, A., Yoon, S.-C., Kim, J.-H., Kim, H., Jeon, H., Sung, M., Kim, B. M., Hong, S. K., Park, R. J., Rupakheti, D., Mahata, K. S., Praveen, P. S., Lawrence, M. G., and Holben, B.: Wintertime aerosol optical and radiative properties in the Kathmandu Valley during the SusKat-ABC field campaign, Atmos. Chem. Phys., 17, 1261712632, https://doi.org/10.5194/acp-17-12617-2017, 2017.

Cong, Z., Kawamura, K., Kang, S., and Fu, P.: Penetration of biomass-burning emissions from South Asia through the Himalayas: new insights from atmospheric organic acids, Nature, 5, 9580, https://doi.org/10.1038/srep09580, 2015.

Decesari, S., Facchini, M. C., Carbone, C., Giulianelli, L., Rinaldi, M., Finessi, E., Fuzzi, S., Marinoni, A., Cristofanelli, P., Duchi, R., Bonasoni, P., Vuillermoz, E., Cozic, J., Jaffrezo, J. L., and Laj, P.: Chemical composition of $\mathrm{PM}_{10}$ and $\mathrm{PM}_{1}$ at the highaltitude Himalayan station Nepal Climate Observatory-Pyramid (NCO-P) (5079 m a.s.1.), Atmos. Chem. Phys., 10, 4583-4596, https://doi.org/10.5194/acp-10-4583-2010, 2010.

Dey, S. and Di Girolamo, L.: A climatology of aerosol optical and microphysical properties over the Indian subcontinent from 9 years (2000-2008) of Multiangle Imaging Spectroradiometer (MISR) data, J. Geophys. Res.-Atmos., 115, D15204, https://doi.org/10.1029/2009JD013395, 2010.

Draxler, R. R. and Hess, G. D.: An overview of the HYSPLIT_4 modeling system for trajectories, dispersion, and deposition, Aust. Meteor. Mag., 47, 295-230, 1998.

Dumka, U. C., Tripathi, S. N., Misra, A., Giles, D. M., Eck, T. F., Sagar, R., and Holben, B. N.: Latitudinal variation of aerosol properties from Indo-Gangetic Plain to central Himalayan foothills during TIGERZ campaign, J. Geophys. Res.Atmos., 119, 4750-4769, https://doi.org/10.1002/2013jd021040, 2014.

Gautam, R., Hsu, N. C., Lau, K.-M., and Kafatos, M.: Aerosol and rainfall variability over the Indian monsoon region: distributions, trends and coupling, Ann. Geophys., 27, 3691-3703, https://doi.org/10.5194/angeo-27-3691-2009, 2009a.

Gautam, R., Hsu, N. C., Lau, K. M., Tsay, S. C., and Kafatos, M.: Enhanced pre-monsoon warming over the Himalayan-Gangetic region from 1979 to 2007, Geophys. Res. Lett., 36, L07704, https://doi.org/10.1029/2009GL037641, 2009b.
Gautam, R., Hsu, N. C., Tsay, S. C., Lau, K. M., Holben, B., Bell, S., Smirnov, A., Li, C., Hansell, R., Ji, Q., Payra, S., Aryal, D., Kayastha, R., and Kim, K. M.: Accumulation of aerosols over the Indo-Gangetic plains and southern slopes of the Himalayas: distribution, properties and radiative effects during the 2009 pre-monsoon season, Atmos. Chem. Phys., 11, 1284112863, https://doi.org/10.5194/acp-11-12841-2011, 2011.

Giles, D. M., Holben, B. N., Eck, T. F., Sinyuk, A., Smirnov, A., Slutsker, I., Dickerson, R. R., Thompson, A. M., and Schafer, J. S.: An analysis of AERONET aerosol absorption properties and classifications representative of aerosol source regions, J. Geophys. Res.-Atmos., 117, D17203, https://doi.org/10.1029/2012jd018127, 2012.

Gogoi, M. M., Moorthy, K. K., Kompalli, S. K., Chaubey, J. P., Babu, S. S., Manoj, M. R., Nair, V. S., and Prabhu, T. P.: Physical and optical properties of aerosols in a free tropospheric environment: Results from long-term observations over western trans-Himalayas, Atmos. Environ., 84, 262-274, https://doi.org/10.1016/j.atmosenv.2013.11.029, 2014.

Guttikunda, S. K., Goel, R., and Pant, P.: Nature of air pollution, emission sources, and management in the Indian cities, Atmos. Environ., 95, 501-510, https://doi.org/10.1016/j.atmosenv.2014.07.006, 2014.

Gyawali, M., Arnott, W. P., Lewis, K., and Moosmüller, H.: In situ aerosol optics in Reno, NV, USA during and after the summer 2008 California wildfires and the influence of absorbing and nonabsorbing organic coatings on spectral light absorption, Atmos. Chem. Phys., 9, 8007-8015, https://doi.org/10.5194/acp-9-80072009, 2009.

Hansen, A. D. A., Rosen, H., and Novakov, T.: The aethalometer - An instrument for the real-time measurement of optical absorption by aerosol particles, Sci. Total Environ., 36, 191-196, https://doi.org/10.1016/0048-9697(84)90265-1, 1984.

Jai Devi, J., Tripathi, S. N., Gupta, T., Singh, B. N., Gopalakrishnan, V., and Dey, S.: Observation-based 3-D view of aerosol radiative properties over Indian Continental Tropical Convergence Zone: implications to regional climate, Tellus B, 63, 971-989, https://doi.org/10.1111/j.1600-0889.2011.00580.x, 2011.

Junkermann, W.: An Ultralight Aircraft as Platform for Research in the Lower Troposphere: System Performance and First Results from Radiation Transfer Studies in Stratiform Aerosol Layers and Broken Cloud Conditions, J. Atmos. Ocean. Tech., 18, 934-946, https://doi.org/10.1175/15200426(2001)018<0934:auaapf>2.0.co;2, 2001.

Kaskaoutis, D. G., Singh, R. P., Gautam, R., Sharma, M., Kosmopoulos, P. G., and Tripathi, S. N.: Variability and trends of aerosol properties over Kanpur, northern India using AERONET data (2001-10), Environ. Res. Lett., 7, 024003, https://doi.org/10.1088/1748-9326/7/2/024003, 2012.

Kuhlmann, J. and Quaas, J.: How can aerosols affect the Asian summer monsoon? Assessment during three consecutive pre-monsoon seasons from CALIPSO satellite data, Atmos. Chem. Phys., 10, 4673-4688, https://doi.org/10.5194/acp10-4673-2010, 2010.

Lau, W.: Atmospheric science: Desert dust and monsoon rain, Nat. Geosci., 7, 255-256, https://doi.org/10.1038/ngeo2115, 2014.

Lawrence, M. G. and Lelieveld, J.: Atmospheric pollutant outflow from southern Asia: a review, Atmos. Chem. Phys., 10, 1101711096, https://doi.org/10.5194/acp-10-11017-2010, 2010. 
Li, C., Bosch, C., Kang, S., Andersson, A., Chen, P., Zhang, Q., Cong, Z., Chen, B., Qin, D., and Gustafsson, O.: Sources of black carbon to the Himalayan-Tibetan Plateau glaciers, Nat. Commun., 7, 12574, dio:10.1038/ncomms12574, 2016.

Lüthi, Z. L., Škerlak, B., Kim, S.-W., Lauer, A., Mues, A., Rupakheti, M., and Kang, S.: Atmospheric brown clouds reach the Tibetan Plateau by crossing the Himalayas, Atmos. Chem. Phys., 15, 6007-6021, https://doi.org/10.5194/acp-156007-2015, 2015.

Marcq, S., Laj, P., Roger, J. C., Villani, P., Sellegri, K., Bonasoni, P., Marinoni, A., Cristofanelli, P., Verza, G. P., and Bergin, M.: Aerosol optical properties and radiative forcing in the high Himalaya based on measurements at the Nepal Climate Observatory-Pyramid site (5079 m a.s.1.), Atmos. Chem. Phys., 10, 5859-5872, https://doi.org/10.5194/acp-105859-2010, 2010.

Marinoni, A., Cristofanelli, P., Laj, P., Duchi, R., Putero, D., Calzolari, F., Landi, T. C., Vuillermoz, E., Maione, M., and Bonasoni, P.: High black carbon and ozone concentrations during pollution transport in the Himalayas: Five years of continuous observations at NCO-P global GAW station, J. Environ. Sci., 25, 1618-1625, https://doi.org/10.1016/S1001-0742(12)60242-3, 2013.

Mues, A., Rupakheti, M., Münkel, C., Lauer, A., Bozem, H., Hoor, P., Butler, T., and Lawrence, M. G.: Investigation of the mixing layer height derived from ceilometer measurements in the Kathmandu Valley and implications for local air quality, Atmos. Chem. Phys., 17, 8157-8176, https://doi.org/10.5194/acp17-8157-2017, 2017.

Neitola, K., Asmi, E., Komppula, M., Hyvärinen, A.-P., Raatikainen, T., Panwar, T. S., Sharma, V. P., and Lihavainen, $\mathrm{H}$.: New particle formation infrequently observed in $\mathrm{Hi}-$ malayan foothills - why?, Atmos. Chem. Phys., 11, 8447-8458, https://doi.org/10.5194/acp-11-8447-2011, 2011.

Padmakumari, B., Maheskumar, R. S., Morwal, S. B., Harikishan, G., Konwar, M., Kulkarni, J. R., and Goswami, B. N.: Aircraft observations of elevated pollution layers near the foothills of the Himalayas during CAIPEEX-2009, Q. J. Roy. Meteor. Soc., 139, 625-638, https://doi.org/10.1002/qj.1989, 2013.

Panday, A. K. and Prinn, R. G.: Diurnal cycle of air pollution in the Kathmandu Valley, Nepal: Observations, J. Geophys. Res.Atmos., 114, D09305, https://doi.org/10.1029/2008JD009777, 2009.

Pandey, S. K., Vinoj, V., Landu, K., and Babu, S. S.: Declining pre-monsoon dust loading over South Asia: Signature of a changing regional climate, Sci. Rep.-UK, 7, 16062, https://doi.org/10.1038/s41598-017-16338-w, 2017.

Putero, D., Landi, T. C., Cristofanelli, P., Marinoni, A., Laj, P., Duchi, R., Calzolari, F., Verza, G. P., and Bonasoni, P.: Influence of open vegetation fires on black carbon and ozone variability in the southern Himalayas (NCO-P, 5079 m a.s.1.), Environ. Pollut., 184, 597-604, https://doi.org/10.1016/j.envpol.2013.09.035, 2014.

Putero, D., Cristofanelli, P., Marinoni, A., Adhikary, B., Duchi, R., Shrestha, S. D., Verza, G. P., Landi, T. C., Calzolari, F., Busetto, M., Agrillo, G., Biancofiore, F., Di Carlo, P., Panday, A. K., Rupakheti, M., and Bonasoni, P.: Seasonal variation of ozone and black carbon observed at Paknajol, an urban site in the Kathmandu Valley, Nepal, Atmos. Chem. Phys., 15, 13957-13971, https://doi.org/10.5194/acp-15-13957-2015, 2015.
Raatikainen, T., Hyvärinen, A. P., Hatakka, J., Panwar, T. S., Hooda, R. K., Sharma, V. P., and Lihavainen, H.: The effect of boundary layer dynamics on aerosol properties at the Indo-Gangetic plains and at the foothills of the Himalayas, Atmos. Environ., 89, 548 555, https://doi.org/10.1016/j.atmosenv.2014.02.058, 2014.

Ramana, M. V., Ramanathan, V., Podgorny, I. A., Pradhan, B. B., and Shrestha, B.: The direct observations of large aerosol radiative forcing in the Himalayan region, Geophys. Res. Lett., 31, L05111, https://doi.org/10.1029/2003GL018824, 2004.

Ramanathan, V., Crutzen, P. J., Kiehl, J. T., and Rosenfeld, D.: Aerosols, Climate, and the Hydrological Cycle, Science, 294, 2119-2124, https://doi.org/10.1126/science.1064034, 2001.

Russell, P. B., Bergstrom, R. W., Shinozuka, Y., Clarke, A. D., DeCarlo, P. F., Jimenez, J. L., Livingston, J. M., Redemann, J., Dubovik, O., and Strawa, A.: Absorption Angstrom Exponent in AERONET and related data as an indicator of aerosol composition, Atmos. Chem. Phys., 10, 1155-1169, https://doi.org/10.5194/acp-10-1155-2010, 2010.

Shrestha, P., Barros, A. P., and Khlystov, A.: Chemical composition and aerosol size distribution of the middle mountain range in the Nepal Himalayas during the 2009 pre-monsoon season, Atmos. Chem. Phys., 10, 11605-11621, https://doi.org/10.5194/acp-1011605-2010, 2010.

Shrestha, P., Barros, A. P., and Khlystov, A.: CCN estimates from bulk hygroscopic growth factors of ambient aerosols during the pre-monsoon season over Central Nepal, Atmos. Environ., 67, 120-129, https://doi.org/10.1016/j.atmosenv.2012.10.042, 2013.

Stone, E. A., Schauer, J. J., Pradhan, B. B., Dangol, P. M., Habib, G., Venkataraman, C., and Ramanathan, V.: Characterization of emissions from South Asian biofuels and application to source apportionment of carbonaceous aerosol in the Himalayas, J. Geophys. Res.-Atmos., 115, D06301, https://doi.org/10.1029/2009JD011881, 2010.

Tripathi, S. N., Dey, S., Tare, V., Satheesh, S. K., Lal, S., and Venkataramani, S.: Enhanced layer of black carbon in a north Indian industrial city, Geophys. Res. Lett., 32, L12802, https://doi.org/10.1029/2005g1022564, 2005.

Venkataraman, C., Habib, G., Kadamba, D., Shrivastava, M., Leon, J. F., Crouzille, B., Boucher, O., and Streets, D. G.: Emissions from open biomass burning in India: Integrating the inventory approach with high-resolution Moderate Resolution Imaging Spectroradiometer (MODIS) active-fire and land cover data, Global Biogeochem. Cy., 20, GB2013, https://doi.org/10.1029/2005GB002547, 2006.

Venzac, H., Sellegri, K., Laj, P., Villani, P., Bonasoni, P., Marinoni, A., Cristofanelli, P., Calzolari, F., Fuzzi, S., Decesari, S., Facchini, M. C., Vuillermoz, E., and Verza, G. P.: High frequency new particle formation in the Himalayas, P. Natl. Acad. Sci. USA, 105, 15666-15671, https://doi.org/10.1073/pnas.0801355105, 2008.

Vinoj, V., Rasch, P. J., Wang, H., Yoon, J.-H., Ma, P.-L., Landu, K., and Singh, B.: Short-term modulation of Indian summer monsoon rainfall by West Asian dust, Nat. Geosci., 7, 308-313, https://doi.org/10.1038/ngeo2107, 2014.

Xie, A., Ren, J., Qin, X., and Kang, S.: Reliability of NCEP/NCAR reanalysis data in the Himalayas/Tibetan Plateau, J. Geogr. Sci., 17, 421-430, https://doi.org/10.1007/s11442-007-0421-2, 2007. 
Yang, M., Howell, S. G., Zhuang, J., and Huebert, B. J.: Attribution of aerosol light absorption to black carbon, brown carbon, and dust in China - interpretations of atmospheric measurements during EAST-AIRE, Atmos. Chem. Phys., 9, 2035-2050, https://doi.org/10.5194/acp-9-2035-2009, 2009. 